\title{
Life-cycle assessment of the contemporary standardized wall systems
}

\author{
Michal Kraus ${ }^{1, *}$, and Petra Nováková ${ }^{1}$ \\ ${ }^{1}$ Institute of Technology and Business in České Budějovice, Department of Civil Engineering, \\ 370 01, České Budějovice, Czech Republic
}

\begin{abstract}
Due to the current environmental situation, the reducing of greenhouse gas emission and the saving energy is the phenomenon. The building sector is still growing and more and more energy is needed. Thermal performance of building envelope has been of great importance in the context of existing global warming issues. Buildings are responsible for $40 \%$ of energy consumption and $36 \%$ of Carbon Dioxide $\left(\mathrm{CO}_{2}\right)$ emissions in the member states of the European Union. According to the research project Heartland Green Sheets, the recommended criteria for assessments of sustainable buildings materials are low embodied energy, recyclable, use renewable resources, locally or regionally produced, energy efficient, low environmental impact, durable, minimize waste, positive social impact and affordable. The contribution focuses on life-cycle assessment (LCA) and sustainability assessment of commonly used wall systems. The multicriteria analysis of the contemporary wall systems in term of sustainable development is presented in the paper. The contemporary commonly used wall systems are assessed in terms of labour, time and financial demands, energy and environmental performance.
\end{abstract}

\section{Introduction}

One of the most difficult problems in the construction industry is to take objective decisions, especially for the choice of material solutions and technologies. The decision process is complicated and time-consuming. The contribution presents a multi-criteria analysis of contemporary wall systems from the point of view of sustainable development, which should help in this decision-making process. According to the research project Heartland Green Sheets, the recommended criteria for assessments of sustainable buildings materials are low embodied energy, recyclable, use renewable resources, locally or regionally produced, energy efficient, low environmental impact, durable, minimize waste, positive social impact and affordable.

The assessed criteria (labour, time and financial demands, thermal and technical properties and environmental aspects) are assessed in relation to the results obtained on the basis of generally available technical documents issued by building materials manufacturers.

\footnotetext{
*Corresponding author: info@krausmichal.cz
} 


\section{Contemporary standardized wall systems}

Twenty different variants of wall systems are compared. The maximum wall thickness is $500 \mathrm{~mm}$. The first three variants are made without additional thermal insulation only by the use of thermal insulating blocks. Variants 4 to 15 represent the use of the external thermal insulation composite system (ETICS). Variants $4-7$ is designed made of the brick thickness of $300 \mathrm{~mm}$ and supplemented with thermal insulation made of white and grey polystyrene, mineral wool and phenolic foam.

Table 1. Overview of assessed standardized wall systems.

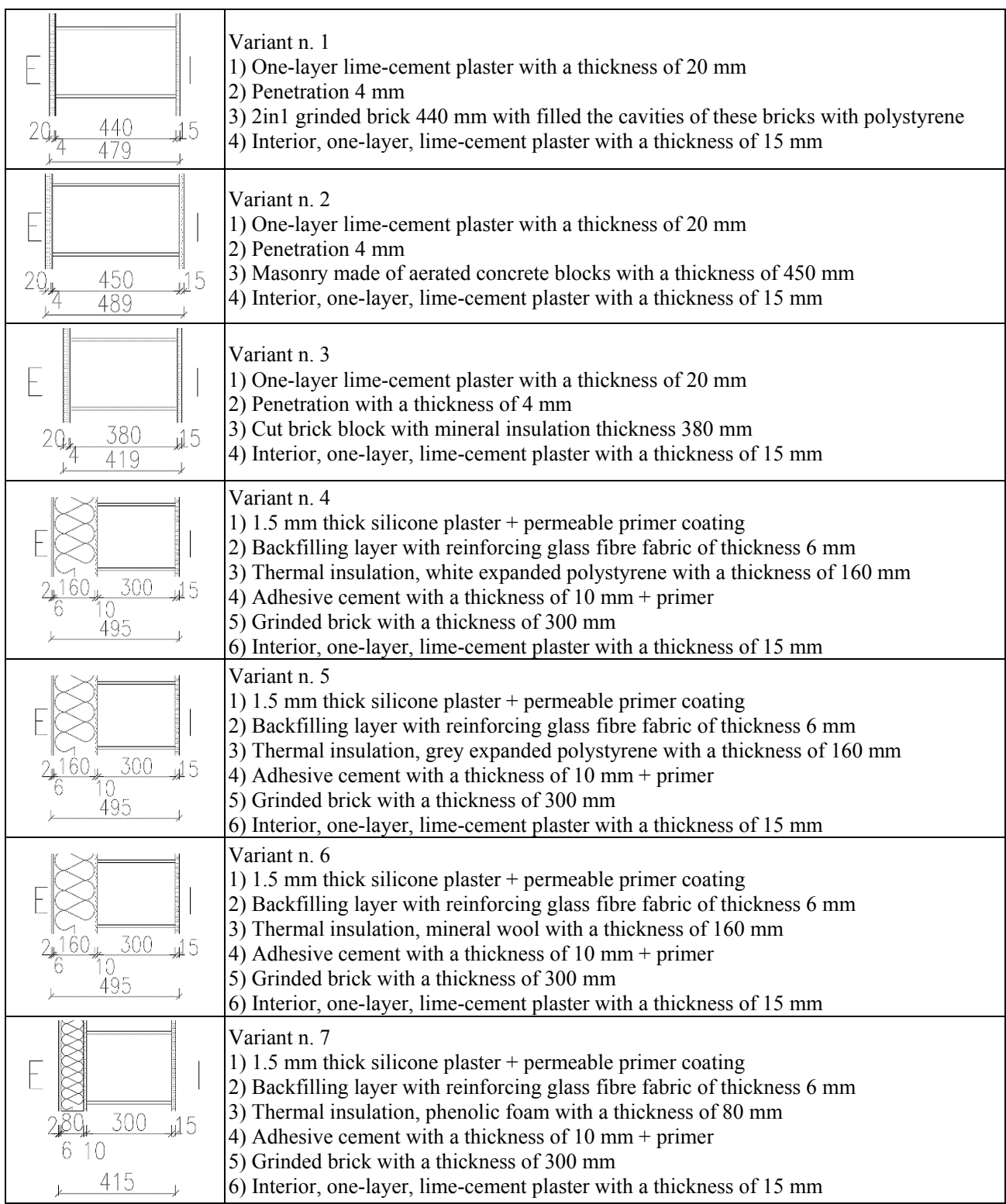




\begin{tabular}{|c|c|}
\hline $\begin{array}{c}2,160,300 \\
6\end{array}$ & $\begin{array}{l}\text { Variant } \mathrm{n} .8 \\
\text { 1) } 1.5 \mathrm{~mm} \text { thick silicone plaster + permeable primer coating } \\
\text { 2) Backfilling layer with reinforcing glass fibre fabric of thickness } 6 \mathrm{~mm} \\
\text { 3) Thermal insulation, white expanded polystyrene with a thickness of } 160 \mathrm{~mm} \\
\text { 4) Adhesive cement with a thickness of } 10 \mathrm{~mm}+\text { primer } \\
\text { 5) Aerated concrete blocks with a thickness of } 300 \mathrm{~mm} \\
\text { 6) Interior, one-layer, lime-cement plaster with a thickness of } 15 \mathrm{~mm}\end{array}$ \\
\hline 300 & $\begin{array}{l}\text { Variant } \mathrm{n} .9 \\
\text { 1) } 1.5 \mathrm{~mm} \text { thick silicone plaster + permeable primer coating } \\
\text { 2) Backfilling layer with reinforcing glass fibre fabric of thickness } 6 \mathrm{~mm} \\
\text { 3) Thermal insulation, grey expanded polystyrene with a thickness of } 160 \mathrm{~mm} \\
\text { 4) Adhesive cement with a thickness of } 10 \mathrm{~mm}+\text { primer } \\
\text { 5) Aerated concrete blocks with a thickness of } 300 \mathrm{~mm} \\
\text { 6) Interior, one-layer, lime-cement plaster with a thickness of } 15 \mathrm{~mm}\end{array}$ \\
\hline & $\begin{array}{l}\text { Variant } \mathrm{n} .10 \\
\text { 1) } 1.5 \mathrm{~mm} \text { thick silicone plaster + permeable primer coating } \\
\text { 2) Backfilling layer with reinforcing glass fibre fabric of thickness } 6 \mathrm{~mm} \\
\text { 3) Thermal insulation, mineral wool with a thickness of } 160 \mathrm{~mm} \\
\text { 4) Adhesive cement with a thickness of } 10 \mathrm{~mm}+\text { primer } \\
\text { 5) Aerated concrete blocks with a thickness of } 300 \mathrm{~mm} \\
\text { 6) Interior, one-layer, lime-cement plaster with a thickness of } 15 \mathrm{~mm} \\
\end{array}$ \\
\hline & $\begin{array}{l}\text { Variant } \mathrm{n} .11 \\
\text { 1) } 1.5 \mathrm{~mm} \text { thick silicone plaster + permeable primer coating } \\
\text { 2) Backfilling layer with reinforcing glass fibre fabric of thickness } 6 \mathrm{~mm} \\
\text { 3) Thermal insulation, Calcium silicate mineral board with a thickness of } 160 \mathrm{~mm} \\
\text { 4) Adhesive cement with a thickness of } 10 \mathrm{~mm}+\text { primer } \\
\text { 5) Aerated concrete blocks with a thickness of } 300 \mathrm{~mm} \\
\text { 6) Interior, one-layer, lime-cement plaster with a thickness of } 15 \mathrm{~mm}\end{array}$ \\
\hline & $\begin{array}{l}\text { Variant } \mathrm{n} .12 \\
\text { 1) } 1.5 \mathrm{~mm} \text { thick silicone plaster + permeable primer coating } \\
\text { 2) Backfilling layer with reinforcing glass fibre fabric of thickness } 6 \mathrm{~mm} \\
\text { 3) Thermal insulation, white expanded polystyrene with a thickness of } 200 \mathrm{~mm} \\
\text { 4) Adhesive cement with a thickness of } 10 \mathrm{~mm}+\text { primer } \\
\text { 5) Sand-lime bricks with a thickness of } 240 \mathrm{~mm} \\
\text { 6) Interior, one-layer, lime-cement plaster with a thickness of } 15 \mathrm{~mm}\end{array}$ \\
\hline & $\begin{array}{l}\text { Variant } \mathrm{n} .13 \\
\text { 1) } 1.5 \mathrm{~mm} \text { thick silicone plaster + permeable primer coating } \\
\text { 2) Backfilling layer with reinforcing glass fibre fabric of thickness } 6 \mathrm{~mm} \\
\text { 3) Thermal insulation, grey expanded polystyrene with a thickness of } 200 \mathrm{~mm} \\
\text { 4) Adhesive cement with a thickness of } 10 \mathrm{~mm}+\text { primer } \\
\text { 5) Sand-lime bricks with a thickness of } 240 \mathrm{~mm} \\
\text { 6) Interior, one-layer, lime-cement plaster with a thickness of } 15 \mathrm{~mm}\end{array}$ \\
\hline$\frac{2}{6}$ & $\begin{array}{l}\text { Variant } \mathrm{n} .14 \\
\text { 1) } 1.5 \mathrm{~mm} \text { thick silicone plaster }+ \text { permeable primer coating } \\
\text { 2) Backfilling layer with reinforcing glass fibre fabric of thickness } 6 \mathrm{~mm} \\
\text { 3) Thermal insulation, mineral wool with a thickness of } 200 \mathrm{~mm} \\
\text { 4) Adhesive cement with a thickness of } 10 \mathrm{~mm}+\text { primer } \\
\text { 5) Sand-lime bricks with a thickness of } 240 \mathrm{~mm} \\
\text { 6) Interior, one-layer, lime-cement plaster with a thickness of } 15 \mathrm{~mm}\end{array}$ \\
\hline 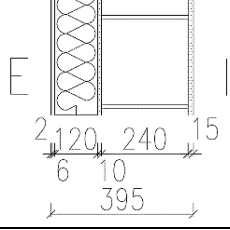 & $\begin{array}{l}\text { Variant } \mathrm{n} .15 \\
\text { 1) } 1.5 \mathrm{~mm} \text { thick silicone plaster + permeable primer coating } \\
\text { 2) Backfilling layer with reinforcing glass fibre fabric of thickness } 6 \mathrm{~mm} \\
\text { 3) Thermal insulation, phenolic foam with a thickness of } 120 \mathrm{~mm} \\
\text { 4) Adhesive cement with a thickness of } 10 \mathrm{~mm}+\text { primer } \\
\text { 5) Sand-lime bricks with a thickness of } 240 \mathrm{~mm} \\
\text { 6) Interior, one-layer, lime-cement plaster with a thickness of } 15 \mathrm{~mm}\end{array}$ \\
\hline
\end{tabular}




\begin{tabular}{|c|c|}
\hline$\frac{2 \pi}{6}$ & $\begin{array}{l}\text { Variant } \mathrm{n} .16 \\
\text { 1) } 1.5 \mathrm{~mm} \text { thick silicone plaster + permeable primer coating } \\
\text { 2) Backfilling layer with reinforcing glass fibre fabric of thickness } 6 \mathrm{~mm} \\
\text { 3) Thermal insulation, white expanded polystyrene with a thickness of } 200 \mathrm{~mm} \\
\text { 4) Adhesive cement with a thickness of } 10 \mathrm{~mm}+\text { primer } \\
\text { 5) Lost formwork and reinforced concrete with a thickness of } 200 \mathrm{~mm} \\
\text { 6) Interior, one-layer, lime-cement plaster with a thickness of } 15 \mathrm{~mm}\end{array}$ \\
\hline & $\begin{array}{l}\text { Variant n. } 17 \\
\text { 1) } 1.5 \mathrm{~mm} \text { thick silicone plaster + permeable primer coating } \\
\text { 2) Backfilling layer with reinforcing glass fibre fabric of thickness } 6 \mathrm{~mm} \\
\text { 3) Thermal insulation, hemp fibre board with a thickness of } 200 \mathrm{~mm} \\
\text { 4) Adhesive cement with a thickness of } 10 \mathrm{~mm}+\text { primer } \\
\text { 5) Lost formwork and reinforced concrete with a thickness of } 200 \mathrm{~mm} \\
\text { 6) Interior, one-layer, lime-cement plaster with a thickness of } 15 \mathrm{~mm}\end{array}$ \\
\hline & $\begin{array}{l}\text { Variant } \mathrm{n} .18 \\
\text { 1) } 1.5 \mathrm{~mm} \text { thick silicone plaster }+ \text { permeable primer coating } \\
\text { 2) Backfilling layer with reinforcing glass fibre fabric of thickness } 6 \mathrm{~mm} \\
\text { 3) Thermal insulation, mineral wool with a thickness of } 200 \mathrm{~mm} \\
\text { 4) Adhesive cement with a thickness of } 10 \mathrm{~mm}+\text { primer } \\
\text { 5) Lost formwork and reinforced concrete with a thickness of } 200 \mathrm{~mm} \\
\text { 6) Interior, one-layer, lime-cement plaster with a thickness of } 15 \mathrm{~mm}\end{array}$ \\
\hline & $\begin{array}{l}\text { Variant } \mathrm{n} .19 \\
\text { 1) } 1.5 \mathrm{~mm} \text { thick silicone plaster + permeable primer coating } \\
\text { 2) Backfilling layer with reinforcing glass fibre fabric of thickness } 6 \mathrm{~mm} \\
\text { 3) Thermal insulation, block of grey polystyrene with a thickness of } 150 \mathrm{~mm} \\
\text { 4) Reinforced concrete with a thickness of } 150 \mathrm{~mm} \\
\text { 5) Thermal insulation, block of grey polystyrene with a thickness of } 50 \mathrm{~mm} \\
\text { 6) Polymer-cement bridge of thickness } 1 \mathrm{~mm} \\
\text { 7) Interior, one-layer, lime-cement plaster with a thickness of } 15 \mathrm{~mm}\end{array}$ \\
\hline $\begin{array}{r}+150,150, \ldots \\
6 \\
+\quad 37150 \\
\end{array}$ & $\begin{array}{l}\text { Variant n. } 20 \\
\text { 1) } 1.5 \mathrm{~mm} \text { thick silicone plaster } \\
\text { 2) Backfilling layer with reinforcing glass fibre fabric of thickness } 6 \mathrm{~mm} \\
\text { 3) Wood fibre board with a thickness of } 60 \mathrm{~mm} \\
\text { 4) Solid Structural Timber+Thermal insulation, mineral wool with a thickness of } 140 \mathrm{~mm} \\
\text { 5) gypsum paper board with vapour barrier with a thickness of } 15 \mathrm{~mm} \\
\text { 6) Solid Structural Timber + Thermal insulation, mineral wool with a thickness of } 60 \mathrm{~mm} \\
\text { 7) Gypsum board with a thickness of } 15 \mathrm{~mm} \\
\text { 8) Interior finish - wallpaper }\end{array}$ \\
\hline
\end{tabular}

\section{Results}

\subsection{Thermal-technical assessment}

The thermal efficiency of building envelopes is of great importance in the context of the existing problems of global warming. Buildings account for $40 \%$ of energy consumption [1]. The main parameter is the value of the heat transfer coefficient U. It expresses how much heat escapes with a surface of $1 \mathrm{~m}^{2}$ when the temperature difference of its surfaces is $1 \mathrm{~K}$. Another important parameter is the annual balance of condensed and evaporable water vapour. If the composition of the structure is designed so that water vapour is not able to evaporate through it, thermal insulation inside the structure is degraded, the risk of mold emergence increases and the thermal insulation properties of the structure are significantly reduced. The results of the thermal-technical assessment of variants are shown in Table 2. 
Table 2. Thermal-technical assessment of assessed standardized wall systems.

\begin{tabular}{|c|c|c|c|}
\hline Var. & $\begin{array}{c}\text { Heat transfer } \\
\text { coefficient } \\
\mathrm{U}\left[\mathrm{W} /\left(\mathrm{m}^{2} \mathrm{~K}\right)\right]\end{array}$ & $\begin{array}{c}\text { Amount of condensed water vapour } \\
\text { per year } \\
\mathrm{M}_{\mathrm{c,a}}\left[\mathrm{kg} /\left(\mathrm{m}^{2} \mathrm{a}\right)\right]\end{array}$ & $\begin{array}{c}\text { The amount of evaporable water } \\
\text { vapour per year } \\
\mathrm{M}_{\mathrm{ev}, \mathrm{a}}\left[\mathrm{kg} /\left(\mathrm{m}^{2} \mathrm{a}\right)\right]\end{array}$ \\
\hline 1 & 0.182 & 0.3234 & 2.7291 \\
\hline 2 & 0.176 & 0.1490 & 2.7174 \\
\hline 3 & 0.174 & 0.1216 & 2.7254 \\
\hline 4 & 0.159 & 0.0101 & 1.0677 \\
\hline 5 & 0.147 & 0.0136 & 2.4027 \\
\hline 6 & 0.162 & 0.1179 & 3.5985 \\
\hline 7 & 0.179 & 0.1220 & 3.6045 \\
\hline 8 & 0.136 & 0.0242 & 0.7775 \\
\hline 9 & 0.127 & 0.0252 & 1.5183 \\
\hline 10 & 0.139 & 0.2075 & 3.5541 \\
\hline 11 & 0.152 & 0.2059 & 3.5611 \\
\hline 12 & 0.169 & 0.0029 & 1.2471 \\
\hline 13 & 0.152 & 0.0057 & 2.4119 \\
\hline 14 & 0.173 & 0.0765 & 3.6190 \\
\hline 15 & 0.168 & 0.0815 & 3.6147 \\
\hline 16 & 0.173 & 0.0009 & 1.4003 \\
\hline 17 & 0.186 & 0.0067 & 6.8705 \\
\hline 18 & 0.178 & 0.0107 & 6.8251 \\
\hline 19 & 0.157 & 0.0021 & 2.5101 \\
\hline 20 & 0.187 & 1.9370 & 1.9370 \\
\hline
\end{tabular}

\subsection{Labor and time consuming implementation}

The time-consuming performance of construction activities is one of the important criteria. Investors and developers generally require the fastest construction process. The period of the construction implementation is related to its labor. This includes not only the construction itself but also the use of construction machinery. The modified workload equation, where $t$ is the time required for construction, $Q$ is the amount of material in the required unit of measure $\left(\mathrm{m}, \mathrm{m}^{2}, \mathrm{~m}^{3}\right)$, and $P$ is the labor performance in hours per worker or machine:

$$
t=Q \cdot P
$$

The resulting labor values are converted to $1 \mathrm{~m}^{2}$ of the external wall. Calculations of the time consuming of each variant are illustrated in the following table.

Table 3. Results of the labor per $1 \mathrm{~m}^{2}$ of building envelope.

\begin{tabular}{|c|c|}
\hline Var. & Labor $\left[\mathrm{Nh} / \mathrm{m}^{2}\right]$ \\
\hline 1 & 2.000 \\
\hline 2 & 1.505 \\
\hline 3 & 1.770 \\
\hline 4 & 2.640 \\
\hline 5 & 2.640 \\
\hline 6 & 2.630 \\
\hline 7 & 2.610 \\
\hline 8 & 2.395 \\
\hline 9 & 2.395 \\
\hline 10 & 2.385 \\
\hline
\end{tabular}

\begin{tabular}{|c|c|}
\hline Var. & Labor $\left[\mathrm{Nh} / \mathrm{m}^{2}\right]$ \\
\hline 11 & 2.302 \\
\hline 12 & 2.180 \\
\hline 13 & 2.180 \\
\hline 14 & 2.170 \\
\hline 15 & 2.150 \\
\hline 16 & 2.589 \\
\hline 17 & 2.569 \\
\hline 18 & 2.579 \\
\hline 19 & 2.391 \\
\hline 20 & 3.326 \\
\hline
\end{tabular}




\subsection{Financial demands - costs}

Table 4 shows the results of the financial demands (costs) of the individual variants. Price calculations are developed in EuroCALC 3 software and the price of the one square meter of the building envelope is calculated. The budgets include not only the prices of the materials, but also the wages of the workers carrying out the construction work.

Table 4. Results of the financial demands.

\begin{tabular}{|c|c|}
\hline Var. & Costs [CZK] \\
\hline 1 & 2201 \\
\hline 2 & 1972 \\
\hline 3 & 2526 \\
\hline 4 & 2350 \\
\hline 5 & 2289 \\
\hline 6 & 2524 \\
\hline 7 & 3018 \\
\hline 8 & 2446 \\
\hline 9 & 2446 \\
\hline 10 & 2620 \\
\hline
\end{tabular}

\begin{tabular}{|c|c|}
\hline Var. & Costs [CZK] \\
\hline 11 & 2539 \\
\hline 12 & 2334 \\
\hline 13 & 2334 \\
\hline 14 & 2559 \\
\hline 15 & 3493 \\
\hline 16 & 2050 \\
\hline 17 & 2540 \\
\hline 18 & 2324 \\
\hline 19 & 2851 \\
\hline 20 & 2980 \\
\hline
\end{tabular}

\subsection{Environmental demands}

Buildings account for $36 \%$ of carbon dioxide $\left(\mathrm{CO}_{2}\right)$ emissions in the Member States of the European Union [1]. The construction sector is responsible for a large number of harmful emissions, accounting for $30 \%$ of greenhouse gas emissions, because of their operation, and a further $18 \%$ indirectly caused by material abuse and transportation [2,3]. During material selection, it is necessary to pay attention not only to how much emissions the material produces after installation to the structure but also how much emissions it produces when the material is produced. The environmental assessment was carried out using the assessment methodology of SBToolCZ. Annual equivalent emissions of Carbon Dioxide and Sulfur Dioxide for each variant are determined (Table 5).

Table 5. Annual equivalent emissions of Carbon Dioxide and Sulfur Dioxide.

\begin{tabular}{|c|c|c|}
\hline Var. & $\begin{array}{c}\text { Annual equivalent } \\
\text { emissions of } \mathrm{CO}_{2} \\
{\left[\left(\mathrm{~kg} \mathrm{CO}_{2, \mathrm{eq}} / \mathrm{a}\right)\right]}\end{array}$ & $\begin{array}{c}\text { Annual equivalent } \\
\text { emissions of } \mathrm{SO}_{2} \\
{\left[\left(\mathrm{~g} \mathrm{SO}_{2, \mathrm{eq}} / \mathrm{a}\right)\right]}\end{array}$ \\
\hline 1 & 1.0026 & 3.0506 \\
\hline 2 & 1.6120 & 4.4734 \\
\hline 3 & 1.0007 & 3.0235 \\
\hline 4 & 0.8004 & 3.3366 \\
\hline 5 & 0.7639 & 3.0166 \\
\hline 6 & 1.2679 & 4.7190 \\
\hline 7 & 1.7375 & 5.3046 \\
\hline 8 & 1.5790 & 5.3474 \\
\hline 9 & 1.5391 & 5.0274 \\
\hline 10 & 2.0431 & 6.7298 \\
\hline
\end{tabular}

\begin{tabular}{|c|c|c|}
\hline Var. & $\begin{array}{c}\text { Annual equivalent } \\
\text { emissions of } \mathrm{CO}_{2} \\
\left.\left[\left(\mathrm{~kg} \mathrm{CO}_{2, \mathrm{eq}} / \mathrm{a}\right)\right]\right]\end{array}$ & $\begin{array}{c}\text { Annual equivalent } \\
\text { emissions of } \mathrm{SO}_{2} \\
{\left[\left(\mathrm{~g} \mathrm{SO}_{2, \mathrm{eq}} / \mathrm{a}\right)\right]}\end{array}$ \\
\hline 11 & 1.6137 & 4.5826 \\
\hline 12 & 1.0469 & 3.1894 \\
\hline 13 & 1.0009 & 2.7894 \\
\hline 14 & 1.6309 & 4.9174 \\
\hline 15 & 2.0389 & 6.4614 \\
\hline 16 & 2.3616 & 10.4148 \\
\hline 17 & 2.1244 & 10.6702 \\
\hline 18 & 2.3156 & 12.1422 \\
\hline 19 & 1.9191 & 8.5577 \\
\hline 20 & 0.3456 & 3.7380 \\
\hline
\end{tabular}

\subsection{Overall evaluation}

The multi-criteria analysis is not a simple process. The overall evaluation is performed so that the values of the monitored parameters for each variant were ranked from best to worst. At the same time, points are assigned to individual variants according to the scale where 1 is the worst value and 20 is the best value. Subsequently, the points were counted and the final order was determined. The results are shown in Table 6. 
Table 6. Overall evaluation.

\begin{tabular}{|c|c|c|c|c|c|c|c|c|c|c|}
\hline \multirow[b]{2}{*}{ Var. } & \multicolumn{2}{|c|}{$\begin{array}{c}\text { Thermal-technical } \\
\text { assessment }\end{array}$} & \multicolumn{2}{|c|}{ Labor } & \multicolumn{2}{|c|}{$\begin{array}{l}\text { Financial } \\
\text { demands }\end{array}$} & \multicolumn{2}{|c|}{$\begin{array}{c}\text { Environmental } \\
\text { demands }\end{array}$} & \multicolumn{2}{|c|}{$\begin{array}{c}\text { Overall } \\
\text { evaluation }\end{array}$} \\
\hline & $\begin{array}{c}\text { Heat transfer } \\
\text { coefficient } \\
\mathrm{U}\left[\mathrm{W} /\left(\mathrm{m}^{2} \mathrm{~K}\right)\right]\end{array}$ & Points & $\begin{array}{c}\text { Labor } \\
{\left[\mathrm{Nh} / \mathrm{m}^{2}\right]}\end{array}$ & Points & $\begin{array}{c}\text { Costs } \\
{[\mathrm{CZK}]}\end{array}$ & Points & Points & Points & $\begin{array}{c}\text { Total } \\
\text { points }\end{array}$ & $\begin{array}{l}\text { Total } \\
\text { rank }\end{array}$ \\
\hline 1 & 0.182 & 3 & 2.000 & 18 & 2201 & 18 & 7.5 & 8.5 & 55 & 4 \\
\hline 2 & 0.176 & 6 & 1.505 & 20 & 1972 & 20 & 5 & 6.5 & 57.5 & 2 \\
\hline 3 & 0.174 & 7 & 1.770 & 19 & 2526 & 9 & 8.5 & 9 & 52.5 & 6 \\
\hline 4 & 0.159 & 13 & 2.640 & 2.5 & 2350 & 13 & 9 & 7.5 & 45 & 10 \\
\hline 5 & 0.147 & 17 & 2.640 & 2.5 & 2289 & 17 & 9.5 & 9.5 & 55.5 & 3 \\
\hline 6 & 0.162 & 12 & 2.630 & 4 & 2524 & 10 & 6.5 & 5.5 & 38 & 13 \\
\hline 7 & 0.179 & 4 & 2.610 & 5 & 3018 & 2 & 3.5 & 4 & 18.5 & 20 \\
\hline 8 & 0.136 & 19 & 2.395 & 9.5 & 2446 & 11.5 & 5.5 & 3.5 & 49 & 8 \\
\hline 9 & 0.127 & 20 & 2.395 & 9.5 & 2446 & 11.5 & 6 & 4.5 & 51.5 & 7 \\
\hline 10 & 0.139 & 18 & 2.385 & 12 & 2620 & 5 & 2 & 2.5 & 39.5 & 11 \\
\hline 11 & 0.152 & 15.5 & 2.302 & 13 & 2539 & 8 & 4.5 & 6 & 47 & 9 \\
\hline 12 & 0.169 & 10 & 2.180 & 14.5 & 2334 & 14.5 & 7 & 8 & 54 & 5 \\
\hline 13 & 0.152 & 15.5 & 2.180 & 14.5 & 2334 & 14.5 & 8 & 10 & 62.5 & 1 \\
\hline 14 & 0.173 & 8.5 & 2.170 & 16 & 2559 & 6 & 4 & 5 & 39.5 & 12 \\
\hline 15 & 0.168 & 11 & 2.150 & 17 & 3493 & 1 & 2.5 & 3 & 34.5 & 15 \\
\hline 16 & 0.173 & 8.5 & 2.589 & 6 & 2050 & 19 & 0.5 & 1.5 & 35.5 & 14 \\
\hline 17 & 0.186 & 2 & 2.569 & 8 & 2540 & 7 & 1.5 & 1 & 19.5 & 19 \\
\hline 18 & 0.178 & 5 & 2.579 & 7 & 2324 & 16 & 1 & 0.5 & 29.5 & 17 \\
\hline 19 & 0.157 & 14 & 2.391 & 11 & 2851 & 4 & 3 & 2 & 34 & 16 \\
\hline 20 & 0.187 & 1 & 3.326 & 1 & 2980 & 3 & 10 & 7 & 22 & 18 \\
\hline
\end{tabular}

\section{Conclusions}

Selection of the optimal wall system is not a simple and quick process. It is desirable to assess variants from all angles - criteria. Buildings are responsible for a considerable part of the consumption of primary energy. It is important to build low-energy buildings, use renewable resources, and focus on materials with low environmental impact. There is a need to reduce the energy consumption and the greenhouse gas emissions of the building sector. In total, 20 different variants of the contemporary standardized wall systems are reviewed. For this purpose, brick structures are selected either as single-layer units or as multi-layered construction in combination with a contact insulation system. Furthermore, pre-monolithic forms of lost formwork are assessed. The last variant of the external walls is the design of a wooden building. In terms of the thermal-technical point, the highest number of points reached variant $\mathrm{n}$. 9. In terms of the time consuming, the shortest time is required by variant $\mathrm{n}$. 2 . In the case of the costs assessment of the financial difficulty, the variant 2 was the best solution. Variant n. 2 also has the lowest cost. From an environmental point of view, variant n. 5 shows the smallest amount of embodied emissions. Assuming that the significance of all criteria is the same, the variant $n .13$ is best - sand-lime bricks supplemented with thermal insulation of grey polystyrene.

This work is supported by the project IGS201809 Multi-criteria optimization of the building envelope design.

\section{References}

1. M. Kraus, D. Kubečková, AMR 1041, 3-6 (2014)

2. B.V. Ventakarama Reddy, K.S. Jagadish, Energy and Buildings 35 (2),129-137 (2003)

3. C. Baglivo, P. M. Congedo, A. Fazio, Building and Environment 82, 467-480 (2014) 